\title{
STRENGTHENING INSTITUTIONS IN THE EFFORT ADAT CUSTOMARY LAW ENFORCEMENT IN ILLEGAL GOLD MINING AREAS AFFECTED
}

\author{
Sujianto, Ikshan, Syofian, MY Tiyas Tinov \\ Universitas Riau \\ e-mail: ikshanfh59@gmail.com
}

\begin{abstract}
Revitalization of customary and legal institutions is very urgent for the sustainability of environmental. Environmental damage due to illegal gold mining has been very alarming which will have an impact on health problems and natural disasters (flooding). This happens regardless of economic problems mainly due to the stagnation of the prices of superior commodities in Kuantan Singingi Regency. other than that based on the results of observations of these researchers also caused by the weakening of customary institutions. The purpose of this study focuses on the customary institutions that exist in this area because in this sub-district they have traditional institutions in the form of people. This research method uses a qualitative approach with data collection techniques with interviews, observation and documentation. Data analysis technique with interactive analysis. The results of the study indicate that there is a weakening of institutional functions of customary law in preventing environmental damage. Whereas in the previous traditional institutions regulating the ways to manage the environment. Other findings of the local government reduced the role of adat in regulating their communities, whereas in some villages it was proven to be able to protect the environment by prioritizing the functions of traditional institutions
\end{abstract}

Keywords: custommary, law, institution, environment, revitalization

\begin{abstract}
Abstrak
Revitalisasi lembaga adat dan hukum sangat mendesak untuk kelestarian lingkungan. Kerusakan lingkungan akibat penambangan emas ilegal telah sangat mengkhawatirkan yang akan berdampak pada masalah kesehatan dan bencana alam (banjir). Masalah ekonomi terutama disebabkan oleh stagnasi harga komoditas unggulan di Kabupaten Kuantan Singingi. selain itu berdasarkan pengamatan para peneliti ini juga disebabkan oleh melemahnya lembaga adat. Tujuan dari penelitian ini adalah bahwa ada lembaga yang ada di daerah ini karena mereka memiliki lembaga tradisional dalam bentuk orang. Penelitian ini menggunakan pendekatan kualitatif dengan teknik pengumpulan data dengan wawancara, observasi dan dokumentasi. Teknik analisis data dengan analisis interaktif. Hasil penelitian menunjukkan bahwa ada melemahnya fungsi kelembagaan dalam mencegah kerusakan lingkungan. Padahal dalam lembaga tradisional yang mengatur sebelumnya cara mengelola lingkungan. Peran adat dalam mengatur komunitas mereka, sedangkan di beberapa desa terbukti mampu melindungi lingkungan dengan memprioritaskan fungsi lembaga tradisional..
\end{abstract}

Kata Kunci : adat, hukum, institusi, lingkungan, revitalisasi

\section{INTRODUCTION}

The existence of traditional institutions and its law in a neighborhood on bebe memelihar pa ra premises area in premises consistent government policy and, in some areas containers and containers by residents at . in the era of $n$ kebijaka implementation of village autonomy should shortly be an opportunity for the government to strengthen the institutions of indigenous villages.

Customs management institutionally earlier to live amid $m$ asyarakat into living rules afford me $n$ da mberikan solutions in various mas ne of wildlife to the people of Indonesia. N Amun akangan bell 
bush in har i fading role. I ni not unconnected in Daera $\mathrm{h}$ Singingi Kuantan district in general and sub Mount Toar kh intestines.

The presence traditional institutions in the county Kuantan ome subdistrict Singingi dib managed to keep and preserve lingkun ga $\mathrm{n}$. Customs management institutionally have a role in maintaining land or land rights alliance by van Vollenhoven called beschikkingsrec $\mathrm{h} t$, the right of position, right to withdraw result, use rights, liens and lease rights (Abubakar, 2012). T emuan (Abubakar, 2012) there are $d$ ua which emphasizes the importance of kelemb a first gaan legal customs and traditional institutions of men finished second alternative legal and customary legal field still rele van to pen yelesaian ne mas today's society.

L embaga customary to have the structure, duties and functions and competence in the completion se $\mathrm{n}$ gketa (Samson, 2014) da $\mathrm{n}$ if it is run properly would be to make traditional institutions still exist (Alting, 2001). S Elain was in K ash patent Kuantan Singingi has several nigari the one that still exists in preserving the environment so that it does not cause damage to plantation land and the river flow area $\mathrm{i}$. L customary air embaga results because they mempekuat the role of traditional institutions in the life of $\mathrm{m}$ asyarakat (Amri, Saam and Thamrin, 2013).

$\mathrm{P}$ artisi white society in protecting the environment is very influential Posit if in strengthening the role of traditional institutions (Lestari, Agussabti and Alibasyah, 2014). The relationship with the case of this study is still urgent because the existence of Indonesian Development from the periphery is one form of giving autonomy rights to the Village. The village as a government entity that ter e ndah given the authority to regulate its own house in accordance with customary law origins. Village Government is the forefront unit of service to community and a major milestone for the success of all programs. Therefore, strengthen Kelemba $\mathrm{g}$ aan Indigenous is a necessity that ti d ak can postponed in an effort to accelerate the realization of prosperity the community as the goal of regional autonomy .

In order to strengthen the village government directs the development of the village of two D esa development concept of 'Building Rural and Village Building. Building a Village is characterized by being given the authority to use a large enough budget in the Village with labor intensive programs by empowering existing resources in the Village. Whereas the concept of the Village Building is a sustainable development that can produce Village independence with products, businesses that have been born from the concept of village development.

Village independence in the context of regional autonomy requires the readiness of social institutions, political and economic village s e ndiri. Therefore improving the function and role of village institutions has a strategic meaning. One of the failure to improve participation that has occurred so far is caused by: (1) the independence of village government from the government structure on, (ii) the practice of village governance that is not yet fully clean and efficient because of the death of the community's control ability so that a provide an opportunity for abuse of authority, (iii) non-compliance helplessness communities to resolve social problems, polit i k and economy itself because of the confusion of structure and barren functions village institutions. In addition to institutional governance, aspects of village independence are also largely determined by the strength of community institutions, especially those that can regulate behavior behavior and limit in environmental damage.

This is confirmed by Korten (1993), stating that development is a process in Where the members of a society's increasing capacity ng perora and their institutions to produce $\mathrm{p}$ Improving the measures are the sustainable and equitable in quality of life according to their aspirations own. In the context of strengthening community groups, changes are needed structural towards local institutions towards improving living standards, productivity, creativity, $\mathrm{p}$ What Knowledge and skills and capacity institutions so that they are always survival and able to adapt to social changes that surround it. Such transformation, wherever possible maybe done independently and for the needs of the community itself . Even if there is intervention from other parties only facilitating. 


\section{METHOD}

The implementation of this research for collecting primary and secondary data using qualitative methods through observation, interviews, and documentation, especially used to describe ( descriptive ) and explain ( explanatory or confirmatory) about the phenomenon of Village Institutions and Customs in the Rehabilitation of Rural Areas after PETI in Gunung Toar District. Primary Data Source of informants research on ant fig Kenagarian prince, chairman of the sub-district village chief forum Mount Toar, events, and documentation. W ith Techniques pengum gathering of data in the interview, ob servasi direct and documentation. A nalisis data used qualitative data analysis interactive

\section{DISCUSSION}

In relation to some literature and its relation to this study, there are differences in seeing village and customary institutional strengthening in overcoming rural areas affected by gold mining without permission in Gunung Toar Subdistrict, this topic describes the institutional aspects and organizational aspects in general that exist in village institutions. and adat in Gunung Toar District. The two aspects are specifically described in institutional and organizational comparison in strengthening the capacity of village and customary institutions.

Table 1. Comparison of institutional and organizational aspects Institutional Aspects

Organizational aspects

\begin{tabular}{|c|c|}
\hline $\begin{array}{l}\text { The main focus is social behavior or } \\
\text { action }\end{array}$ & $\begin{array}{l}\text { The main focus is the study of structure } \\
\text { organization } \mathrm{i}\end{array}$ \\
\hline $\begin{array}{l}\text { The core of the study is values, rules, and } \\
\text { norms }\end{array}$ & The core study is the role (roles) \\
\hline $\begin{array}{l}3 \text { Aspects of further study on custome, } \\
\text { mores, folkways, usage, trust, morals, ideas, } \\
\text { ideas, doctrines, desires, needs, patterns of } \\
\text { behavior, functions of order, and needs. }\end{array}$ & $\begin{array}{l}\text { Further aspects of the study; roles, } \\
\text { activities, relationships between roles, social } \\
\text { integrase, general structure, comparison of } \\
\text { textual relationships with real structure } \\
\text { relations, structures, power authority } \\
\text { structures, relations of activities and } \\
\text { objectives, aspects of social property, profiles, } \\
\text { and patterns of power. }\end{array}$ \\
\hline
\end{tabular}

\begin{tabular}{clcc}
\hline 4 & The form of social change is cultural & Forms of structural social change \\
\hline 5 & $\begin{array}{c}\text { The length of time in the process of } \\
\text { change is needed long }\end{array}$ & $\begin{array}{c}\text { Changes in organizational aspects are } \\
\text { relatively faster }\end{array}$ \\
\hline 6 & More abstract and dynamic nature & More visual and static & \\
\hline 7 & Institution is more on social change & $\begin{array}{c}\text { Being in the study of organizational } \\
\text { structure }\end{array}$ \\
\hline
\end{tabular}


Based on institutional and organizational comparison aspects in strengthening institutional capacities that become the object of research conducted by researchers, from the Institutional aspect The research findings show in a general description of the profile of village and adat institutional strengthening that there have been changes in social actions that exist in the village government in the Gunung Toar sub-district, this is because the village government since the implementation of the policy on village law number 6 of 2014 has included institutional problems and environment in the problems faced by the village.

This problem was included in the village policy and planning in 2015 simultaneously by the villages in Gunung Toar District. this was answered when the researcher conducted an interview with the Chairperson of the Village Head Forum in Gunung Toar District (Bapak Yusrizal, 22 July 2018) We have already entered into the problem of environmental problems in the village medium term development plan, because it is generally influenced by our human resources who have not been sufficient to carry out public health services. This normative answer is seen from the aspect of governance already included in the policy process, namely the formulation and legitimacy process by the village government. The institutions referred to by the village head's forum chairman are; Government Institutions and Community Institutions.

Government institutions consist of the Village Head, Village Secretary, Village Framework, and Village Consultative Body. Whereas Social Institutions consist of LPM, PKK, Posyandu, Pengajian, Arisan, Savings and Loans, Farmer Groups, Gapoktan, Karang Taruna, Risma, Ormas / NGOs. Based on the results of interviews and research observers in the aspects of social action carried out by stakeholders in the village government there were no significant changes, these institutions went according to the direction of the village head and in formal activities only, except the activities carried out by the assessment groups carried out $\mathrm{n}$ with a schedule in accordance with the conditions of the village in Gunung Toar Subdistrict, such as those conducted by the Pengajian Group in Seberang Sungai Village, conducted once a month.

Furthermore, in the organizational aspect of the structure of the organizations these institutions have been legally established by the rules made by the village government. However, based on the results of a real study, environmental problems have been made in each village in Gunung Toar Subdistrict, there are no institutions that specifically take care of environmental problems in the structural village government institutions. So that environmental problems only exist in the Village RPJM and not in RKPDesa for the implementation of policies in the form of programs and activities in each village in Gunung $\mathrm{T}$ oar subdistrict .

Progrman The activities of the village government are focused on the development of road infrastructure because it has been lagging behind in infrastructure development. However, from the four Koto in Kenagarian Empat Koto Gunung, there is one vehicle that has succeeded in making a structure for changes in social action in the handling of unlicensed gold mining because it is against environmental law in accordance with customary law in the Gunung Toar District.

This action was initiated by kenagarian lubuk stretched out in cooperation with 4 villages which are indeed under the Kenagarian Lubuk customary power area stretching. The village in Kenagarian is the first Lubuk Terentang Village, Pisang Berebus Village, Siberobah Village and Kampung Baru Village, some of which are under the Kenagarian Lubuk Terentang and Kenagarian Toar areas. In this structure is accommodated by customary law with cooperation between villages in protecting the environment from gold mining.

The stakeholders involved in this Policy were initiated by Penghulu Pucuk and were followed by four datasets in Kenegerian Lubuk Terentang followed by the Head of Pisang Berebus Village, Head of the Lubuk Terentang Village, Kampung Baru Village Head, Siberobah Village Head and attended by the BPD Chairperson from four villages, the Youth Chair of four villages made joint arrangements. The 
results of this social action from this policy of illegal gold miners (PETI) resulted in the inability of miners to enter the Kuantan river area in the rural areas of these four villages. This success occurs because there is integrity from the staeholders involved in general community policy and support. Whereas for other rural areas outside these four villages cases have occurred because there is no integrity from indigenous stakeholders and des a.

The success of one Koto is not separated from the adoption of values, norms, rules of local wisdom and conducted collaboratively in a bottom-up and top-down manner. This is with the existence of roles, activities, relationships between roles, social integration, general structure, comparison of textual relationships with real structural relations, structures, power authority structures, relations of activities and objectives, aspects of solubility, profiles, and patterns of power to institutions Dasn Adat village in Kenagarian Lubuk stretches out.

Based on the results of interviews and observations of general profiles Village Institutional Strengthening has been carried out in government aspects by providing training and debriefing to government apparatus and community institutions in the Gunung Toar sub-district, but the aspect of strengthening is by increasing the potential of local wisdom with customary law that begins to revitalize new customary law was carried out by Kenagrian Lubuk Spread with the existence of a joint policy in overcoming environmental problems.

Different from the three kenagarian as a whole mersa not involved in regulating the environment and feel there is a weakening of customary law and norms. This is in accordance with the results of interviews with the prince shoots kenagrian Toar and Datuk Majo in Kenagrian Gulf Beringin, the language is almost the same, "Once customary in managing the environment is kept as an example down to the paddy and beladang always ask for approval of the Indigenous" now with the private ownership of the land is gone in mine".

Based on the results of this interview, there was also support from the chairman of the head of the village chief for the last five years, there was no meeting with ninik mamak on those in the kenagarian to discuss issues of customary law and the environment. In addition, the field findings from the recognition of the gold miners are that they are active in the region The village was blessed with permission at the village level, both the village head, youth, and the wishes of the landowners because of the organization and economic community. Unlike what happened in the advent of koto lubuk terentang adat, villages and young people did not want to cooperate in terms of gold mining, so this became a capital in social, legal, norms and the implementation of formulated policies.

Based on the institutional and organizational aspects found a general profile of the strengthening of village and customary institutions that human resources in village government institutions already have training, customary institutions have not been included in village groups, in general customary law does not work due to lack of integrity of village officials and traditional leaders in the pen impact repayment with the reason there is no other income solution because of the effect of the decline in rubber prices.

\section{CONCLUSION}

A capacity strengthening village institutions and customs of the identified social capital development of cultural capital (cultural capital), human capital (human capital) da $\mathrm{n}$ backed by economic capital (economic capital). demanding participation from the community, coordinating institutions with stakeholders and granting desentarilization rights, transparency activities, valid for all parties, including the community and the government. Strengthening institutions and indigenous villages in the district of Mount Toar can be initiated by means of restoring public confidence in the ninik mamak to the existence of informal institutions that had been there from a long time. When trust can be restored, 
then the community's concern and optimism are expected for various efforts to increase the capacity of local institutions .

The results of the interim study show that the village and customary levels in the study sites tend to want a pattern of collaboration in the institutional development. This finding implies that one of the stages in the institutional strengthening strategy is seen in the identification aspects of basic needs. In the context of the ex-adat institution, there was a weakening of functions because of the economic and political factors of the customary adat, this happened because of economic limitations and knowledge of the ninik mamak. Meanwhile, the Village Government has not been able to implement the policy because it lacks understanding in the polarization of rural development. In addition, because the ownership of the land is individual.

\section{SUGGESTION}

Strengthening Indigenous Institutions should be a movement by the local government in order aga menaj environmental sustainability

\section{DAFTAR PUSTAKA}

\section{Journal}

[1]. Abubakar, L. (2012) ' Revitalizing Customary Law As A Source Of Law In Building Indonesia's Legal System ', Journal Of Legal Dynamics , 21 (1), Pp. 319 - 331.

[2]. Alting, H. (2001) ' (A Study On Ternate Indigenous Legal Communities) ' , Journal Of Legal Dynamics , (Ix).

[3]. Amri, F., Saam, Z. And Thamri N (2013) ' Lubuk Local Wisdom Prohibits As An Effort ' , University Of Riau Center For Environmental Research 35 , (1), Pp. 1-11.

[4]. Lestari, T., A Gussabti And Alibasyah, M. R. (2014) ' Participation Of Indigenous Peoples In The Conservation Of Forest Resources In The Subdistrict Of Central Java District Of Aceh Besar ' , Journal Of Land Resource Management, 3 (2), Pp. 506 - 517.

[5]. Samsul, I. (2014) ' Alternatif Institution Of Completion Of The Strengthening The Trust Institutions As An (A Study On The Customary Institution In Banyu Asin Distric, Province Of South Sumatra And Province Of Papua) ', State Of Law , 5 (2 ), Pp. 127 - 142.

\section{Books}

[6]. Agus Salim \& Romiyatun (Pny.). 2002. Social Change: Sketch Of The Theory And Reflection Of The Indonesian Case Methodology. First Print. Yogya: Tiara Wacana.

[7]. Budi Rajab. 1996. Cultural Plurality Of Indonesian People. Prisma Magazine. 6: 3-13.

[8]. Bambang Rudito, A.P. \& Kusairi (Pny.). 2003. Access To Community Participation: Further Understanding Community Development. First Print. Jakarta: Sinar Harapan Library. 
[9]. Bhenyamin Hoessein. 2002. Decentralization Policy, Local Government, State Administration Journal 2 (2): 1-5.

[10]. Christensen, Clayton, 2011. The Innovator's Dilemma: The Revolutionary Book Taht Will Change The Way You Do Busisness, New York: Harper Business.

[11]. Cooley \& Davis. 1993. Some Sociological Theories Of Community Structure. Happened.

[12]. Darsono Wisadirana. 2004. Rural Sociology, Malang: Umm Press.

[13]. Durkheim, E. 1993. The Division Of Labor In Society. Happened. George Simpson, New York: Free Press.

[14]. Emustian Rahman, Tien Marni, Zulkarnain, 2003. Alam Melayu, A Number Of Ideas To Pick Up The Greatness.

[15]. Engles, F. 1939. Anti Duhring: Herr Eugen Duhring's Revolution In Science. Happened. Emile B. New York: Internat Publ.

[16]. Eitzen \& Zinn. 2001. "In Conflict And Order: Understanding Society". In Abdul Halim Hamid. (Pny.). Recognizing Social Institutions. P. 44-56. Medium: Publishers Of Universiti Putra Malaysia.

[17]. Fred Eggan, Evans-Pritchard, E.E. \& Radclffe-Brown, A.R. 1980. Structure And Function In Primitive Societies. Kuala Lumpur: Language And Library Board.

[18]. Geertz, Clifford. 1981. Brother, Santri And Priyayi In Javanese Society. Jakarta: Jaya Library.

[19]. Hans Antlov. 2003. Countries In The Village: Patronage Of Local Leadership. Jogjakarta: Lapera Pustaka Utama.

[20]. Haw Widjaja. 2001. Village / Clan Government, Based On Law Number 22 Of 1999 Concerning Regional Government. First Print. Jakarta: Raja Grafindo Persada.

[21]. Hasan Mat Nor. 1996. Land And Indigenous People: Study Of Cases In Four Native Villages In Batang Padang Area, Perak. Bangi: Publisher Of Universiti Kebangsaan Malaysia.

[22]. Hasan Yunus. 1993/1994. Documentation Of Riau Malay Manuscripts And Special Studies: Riau Cultural Arts Development And Development Project. Pekanbaru: Riau Regional Government I.

[23]. Harsja, W.B. 1985. Bureaucracy And Culture. First Print. Jakarta: Gramedia.

[24]. Joseph, S.R. 1951. Social Control. New York: D Van Nostrand.

[25]. Kasali. R. (2003). Social Capital: Trust And Entrepreneurship: A Microeconomic Approach To Achieve A Balance Society Usahawan Magazine No. 11 / Th. Xxxii. Fe Ui Management Institute. Jakarta. 
[26]. Kasali. R. 2017. Disruption; Facing Invisible Opponents In Uber Civilization, Jakarta: Gramedia Library.

[27]. Korten. 1993. Human Development Report People's Participation; United Nations Development Program

[28]. Kuntowijoyo. 1999. Culture And Society. Second Print. Yogya: Tiara Wacana.

[29]. Kusnaedi. 1995. Building Village Guidelines For Idt Activists Students And Village Development Cadres. First Print. Jakarta: Spreading Self-Help.

[30]. Li, T.M. 2002. The Process Of Transforming Rural Areas In Indonesia. Transforming The Indonesian Upland: Marginality, Power And Production. Happened. Sumitro \& Kartikasari, Sn. Ed. First. Jakarta: Indonesian Torch Foundation.

[31]. Mohd Aris Haji Othman. 1985. Malay Ethnic Identity. Petaling Jaya: Siri Community Of Fajar Bakti.

[32]. Muchtar Lutfi, Suwardi, Anwar Syair, \& Umar Amin. 1977. History Of Riau. Pekanbaru: Riau Regional Government I. Riau Printing.

[34]. Mubyarto. 1993. Riau Looks At The Future. Yogyakarta: Aditya Media.

[35]. Nasroen, 1974, Basics Of Minangkabau Customary Philosophy, Cv. Pasaman Publisher, Jakarta

[36]. Nonet, P. And P. Selznick. 2007. Responsive Law. Bandung: Nusa Media.

[37]. Ndraha, T. 1990. Community Development. Bandung: Renika Cipta.

[38]. Norazit Strait. 2001. Malay Custom: Continuity And Change. In Abdul Latiff Abu Bakar (Gr.). Customary Malay Allied: Custom Jointed Syarak, Syarak Jointed By Kitabullah. P. 14-23. Kuala Lumpur: Universiti Malaya.

[39]. Nurhadi, 2008. Role Of Social Capital In Economic Development. Research Report (Not Published).

[40]. Quarles Philip Van Ufford, Et Al. 1988. Local Leadership And Program Implementation. Local Leadership And Program Implementation. Happened. Shirley. First Print. Jakarta: Gramedia.

[41]. Rahardjo, S. 1997. Development Of National Law And Social Change, National Legal Identity, Yogyakarta: Faculty Of Law Univ. Indonesian Islam

[42]. Riggs, F.W. 1991. Bureaucratic Culture In Indonesia. In Alfian \& Nazaruddin Syamsuddin (Pny.). Profile Of Indonesian Political Culture. P. 223-231. Jakarta: Graffiti.

[44]. Robert Maciver \& Charles H.P. 1983. Islam And Sociocultural Change: Islamic Studies Of Changing Societies. Kuala Lumpur: Antara Library. 
[45]. Rochim Wirjomidjojo, S. 1987. Creating A Progressive Rural Structure. Jakarta: Yasaguna.

[46]. Rondinelli \& Ruddle. 2003. Rural Sociology. Jogyakarta: Lapera Pustaka Utama.

[47]. Soerjono Soekanto, 1999, Sociological Theory Of Social Change, Ghalia Indonesia: Jakarta.

[48]. Soerjono Soekanto, 200 2, Introduction To Sociology, Cv Rajawali, Jakarta. Selo

[49]. Soemardjan And Soemardi, 1974, Flower Sociology, Felu: Jakarta.

[50]. Selo Soemardjan. 1986. Social Change In Yogyakarta. Jogjakarta: Gadjah Mada University Press.

[51]. Suhirman And Endah Apriani. (2003). When Citizens Assess: Portrait Of Customer Satisfaction In Bandung City Public Service 2002. Bandung: Institute Of Governance Studies.

[52]. Sumpeno, Wahjudin, 2011, "Medium-Term Village Development Plan", The World Bank, Aceh.

[53]. Sudaryono. 2002. Integrated Watershed Management (Das), The Concept Of Sustainable Development. Jurnal Teknologi Lingkungan.

[54]. Sudarwanto, S. 2013. "Legal Aspects Of Watershed Management Based On Government Regulation Number 37 Of 2012 Concerning Watershed Management" National Seminar On Watershed Management Technology Research Results.

[55]. Sujianto, Et Al. 1996. Development Of Isolated Communities For The Preparation Of Full Development Planning Of Isolated Communities In The Village Of Bekawan, Mandah District, Inderagiri Hilir Regency.

[56]. In Idp-Idt Support Project - Oecf In Riau Province. The Development Of Isolated Communities For The Preparation Of Full Development Planning For Isolated Communities In Riau. P. 1- 42. Pekanbaru: Bappeda Tk. I. Riau - Lpm-Unri,

[57]. Et Al. 1997. Assessment Of The Empowerment Of Functions Of Rural Institutions As Supporting The Implementation Of Regional Autonomy (Empowerment Study Of Village Community Resilience Institutions And Village Consultative Institutions In Riau Province). Pekanbaru: Bappeda Tk. I Riau - P2bkm-Unri .

[58]. Et Al. 1998. Research On Social Development Strategies For Developing Marginal Communities (Isolated People) In Coastal Areas Of Bengkalis Regency. Research Project For Isolated Communities In The Coastal Area Of Bengkalis Regency. The Fiscal Year 1997/1998. Pekanbaru: Bengkalis Second Level Regional Government - P2bkm-Unri

[59]. Et Al. 1999. Preservation Of Sakai Community And Culture Sebangar Village, Mandau District. Pekanbaru: Malay Culture Network - Unri P2bkm . 
[60].

Et Al. 2000. Economic Development Strategy For Marginal Communities In Indragiri Hilir (Study Of The Implementation Of Public Policy In Indragiri Hilir District). Pekanbaru: University Of Riau Project - Lpm-Unri

[61].. Et Al. 2001. Profile Of Malay Villages In The Siak River. Malay Community Development Project On The Siak River Banks. Pekanbaru: Provincial Regional Government P2bkm-Unri.

[62]. Surya Maulana. 2002. Institutions Of Coastal And Island Communities: A Cultural Review For The Empowerment Of Coastal And Island Communities. Pekanbaru: Coremap And Critic .

[63]. 2003. Bengkalis Traditional Culture, Pekanbaru: Office Of Culture And Tourism In Collaboration With The Center For The Study Of Malay Language And Culture At The University Of Riau. Uphoff, Norman. 1986. Local Institutional Development: An Analytical Sourcebook With Cases. New York: Kumaran Press.

[64]. 2008. Development Of Social Capital For Disadvantaged Regions. Pekanbaru: Alaf Riau .

[65]. . 2010. Poverty And Empowerment; Evaluation Of Urban Poverty Reduction Programs In Pelalawan District. Pekanbaru: Alaf Riau .

[66]. 2010. Local Institutions; Concept And Reality. Pekanbaru: Alaf Riau .

[67]. . 2012. Development Of A Model Public Organization In Local Communities. Pekanbaru: Alaf Riau .

[68]. . 2014. Policy Model Of Development And Empowerment Of Border Areas Prone To Conflict To Towards Independent Communities. Research Institute, Riau University .

[69]. Et Al. 2016. Institutional Development Model In The Implementation Of Social Capital Of The Rubber Plantation Society In Kuantan Singingi District (Results Of The Mp3ei For The First Year). Questions, B. L.,

[70]. Simanjuntak, Y.N And M. Y. Hage. 2010. Legal Theory Of Cross-Space And Generational Human Order Strategy. Surabaya: Genta Publishing.

[72]. William Hampton. 1990. Local Government And Urban Polities, London And New York: Longman 